\title{
Introduction: Reforming Education for Transformation: Opportunities and challenges
}

\author{
MARK GINSBURG, \\ STEPHEN F. MOSELEY \\ AND MARY JOY PIGOZZI
}

This year, 2010, is a particular moment for the development community, as the world's leaders gather in September at the United Nations to review and recommit to the Millennium Development Goals (MDGs). They will find at the heart of the eight goals that the greatest progress in the past decade has been on goal 2: achieving universal primary education. They will see that data measuring the achievement of the other seven goals is highly dependant on meeting the Education for All (EFA) agenda from early childhood education, through full schooling, as well as including adult literacy and the education of girls and women. The steady commitment of the world education leaders and most of the countries' presidents to the common EFA agenda has laid the foundation for meeting the other goals of eradicating extreme poverty and hunger, promoting gender quality and empowering women, reducing child mortality, improving maternal health, combating acquired immuno-deficiency syndrome (AIDS), malaria, and other diseases, ensuring environmental sustainability, and achieving a more lasting global partnership. Based on the progress over the last 25 years in nearly every nation, we now know that universal-combined effort can make a difference.

Readers, this issue of Development will note that development and opportunities for the future center on the fundamental role of education with its many facets and complexities. The development community around the world must make the years beyond 2010 ones of renewed commitment to understanding education as at the heart of our societies and all individuals participating in their own and their society's development.

In our introduction we examine whether and how education can contribute to societal transformation. Our focus is on transforming society - nationally and globally - towards a reality in which human rights are recognized and experienced by all people. While acknowledging that education is only one institution that contributes to securing human rights for all, we focus on the opportunities and challenges in reforming (or even transforming) education toward achieving this goal. We first discuss how access to quality education is a human right, which in turn can promote understanding and commitment to other human rights. In this regard, educational institutions should not only 
transmit knowledge about and capacities to realize human rights; they must also institutionalize respect for human rights in the ways that they are organized and the processes that are undertaken within them.

\section{The right to education and education for human rights}

Article 26 of the UN Declaration of Human Rights (United Nations, 1948) grants to 'all peoples and all nations' the right to free and compulsory 'education. ... at least in the elementary ... stage', as well as the availability and merit-based access to 'technical and professional education ... and higher education'. It is important to note that the right of access to education is complemented in this article by the right that 'education ... be directed to ... the strengthening of respect for human rights and fundamental freedoms'. The central role of education in promoting and protecting human rights is also articulated in the Preamble of the Declaration: 'every individual and every organ of society ... shall strive by teaching and education to promote respect for these rights and freedoms.'

Every person - 'without distinction of any kind, such as race, color, sex, language, religion, political or other opinion, national or social origin, property, birth or ... the political, jurisdictional or international status of the country or territory to which a person belongs' (Article 2) - should enjoy such rights, including those in the following categories. ${ }^{1}$

- Economic/Welfare: 'own property alone as well as in association with others' (Article 17); 'free choice of employment, ... just and favorable conditions of work, ... just and favorable remuneration [in work] ... and [freedom] to join trade unions for the protection of [one's interests' (Article 23); 'a standard of living adequate for the health and well-being of [one]self and of [one's] family, including food, clothing, housing and medical care and necessary social services' (Article 25);

- Political/Civil: not being 'subjected to torture or to cruel, inhuman or degrading treatment or punishment' (Article 5); 'equal protection of the arrest, detention or exile' (Article 9); 'a fair and public hearing by an independent and impartial tribunal' (Article 10); 'freedom of movement and residence within the borders of each state ... [and] to leave any country ... and to return to his country' (Article 13); 'take part in the government of [one's] country, directly or through freely chosen representatives' (Article 23); and

- Social/Cultural: 'freedom of thought, conscience and religion' (Article 18); 'freedom of opinion and expression ... and to seek, receive and impart information and ideas through any media and regardless of frontiers' (Article 19); 'freely participate in the cultural life of the community, ... enjoy the arts, and ... share in scientific advancement and its benefits' (Article 27).

The responsibility for promoting and protecting human rights is a major one for education. It involves providing access to education, starting with elementary education, organizing education so it does not violate rights, and preparing individuals to understand, promote, and protect their own rights and those of all other human beings (Bernstein Tarrow, 1987; Spring, 2000). In addition, education needs to prepare people to take up human rights not only in families, local communities, and nations, but also on a global scale. As the Declaration states, human beings have the right 'to a social and international order in which the rights and freedoms set forth in this Declaration can be fully realized' (Article 28).

Education has other purposes as well. There is an active discourse around the purposes and definition of quality in education. For example, Pigozzi (2010) argues that issues of quality have become critical in relation to the larger global economic agenda because: proxy measures of quality are no longer acceptable, monitoring student performance has provided a window onto how well (or not) education systems are performing, better data have provided insight into unevenness of quality within and between education systems pointing to institutional inequities, and migration and urbanization are placing fresh demands on education, especially with regard to questions surrounding individual and group identity. Attention must be given to the right to education in all its dimensions. 


\section{Ginsburg et al: Introduction}

\section{Education as a contributor to transforming or reproducing society}

At present, we are not living in a world where all people can realize the full range of human rights including the right to education - as set out in the Declaration. To contribute to building a world in which such rights are realized, educational system policies and structures in all countries need to be transformed, while at the same time the content and processes of education have to be altered so they more effectively contribute to economic, political, and social/cultural transformation of local, national, and global communities.

However, many scholars have concluded that schools and higher-education institutions often play the opposite role; that is, they contribute to economic, political, and social/cultural reproduction of existing human relations, nationally (Bourdieu and Passeron, 1977; Morrow and Torres, 1995) and internationally (Altbach and Kelly, 1978; Brown and Lauder, 1997). Some researchers have identified cases in which students or teachers resist these reproductive processes (Giroux, 1983; Ginsburg, 1995) and some have discussed how education can transform society (Counts, 1932; Kreisberg, 1992). Education seems more often to be a reproductive force - providing unequal access to learning opportunities, preserving structures that limit at least some groups from realizing of human rights, and transmitting ideologies the legitimate structures or discourage people from trying to transform them (Tomasevski, 2006).

\section{The meanings of educational reform}

The term reform indicates at least a rhetorical commitment to change and/or implementation to meet certain goals and objectives. Educational reform may focus on one or more of the following aspects of the system: (a) size (i.e., the number of students, teachers, administrators, and buildings); (b) goals and objectives; (c) policy-making and governance/management structures; (d) system organization (i.e., the types, statuses, and levels of as well as links and ages of transition between institutions); (e) financing and budget making processes; (f) level of funding; (g) curriculum; (h) pedagogy; (i) procedures/criteria for evaluation and promotion of students; (j) procedures/criteria for hiring, evaluation, and promotion of teachers and administrators; and (k) degree/types of involvement of parents, civil society, and private sector. Some reform initiatives within each category may be governed by concerns for institutionalizing and promoting human rights, but this is not necessarily the case.

Educational reform has a long, if not always remembered, history (e.g., Quick, 1868; Simmons 1983). Furthermore, what is labelled as "educational reform' is not always concerned with changing, let alone improving, education. It might only reflect rhetoric without accompanying action (Ginsburg and Cooper, 1994). Moreover, actions viewed as promoting constructive change by one group may be viewed by others as either destructive change or regression (Paulston, 1996). It is important to note as well that, although it is likely that there is a constant need for improving education, some educational reform rhetoric and action is stimulated as much, if not more, by economic and political 'problems' as educational ones.

In attempting to explain the timing and focus of educational reform one might be tempted to restrict one's analysis to dynamics and actors within nation-states or their subunits. However, while clearly important, a national level focus deflects attention from the equally important global or world system level cultural, political, and economic developments (Ginsburg, 1991; Daun, 2002). This is the case for 'developed' countries as well as for 'developing' countries, but particularly in relation to educational reform in the latter societies, we need to pay attention to the activities of multilateral and bilateral agencies, non-governmental organizations, multinational corporations, philanthropic foundations, and universities, which may have different agendas than those of some nations.

\section{The shift from access to quality in educational reform}

The publication of Beeby's (1966) widely read and discussed volume, The Quality of Education in 
Developing Countries, provides evidence that the issue of educational quality has been on the international development agenda for at least 60 years. However, until recently, the quantitative dimension of education has been a more salient concern. Universal primary education, for example, is the goal of international organizations, driven in large part by the notion that access to education is a human right.

The international discourse began to shift in the 1980s and 1990s, as signaled by the 1990 World Conference on EFA: Meeting Basic Learning Needs, which was jointly organized by United Nations Development Programme (UNDP), United Nations Educational, Scientific and Cultural Organization (UNESCO), United Nations Children's Fund (UNICEF), and the World Bank, in Jomtien, Thailand, 5-9 March 1990. The World Declaration on EFA, adopted by those attending the Conference, states that 'basic education services of quality should be expanded' (Inter-Agency Commission, 1990, Article III; emphasis added). Nevertheless, quantitative expansion of educational provision (i.e., education for all, including attention to access, efficiency, and equity) continued to overshadow - and sometimes undermine - quality issues during last decade of the twentieth century.

A ten-year follow-up meeting in Dakar, Senegal, also co-sponsored UNDP, UNESCO, UNICEF, and the World Bank, approved the 'Dakar Framework'. This 2000 document similarly calls for 'governments and all other EFA partners [to] work together to ensure basic education of quality for all, regardless of gender, wealth, location, language or ethnic origin' (UNESCO, 2000: 17; emphasis added). And even though the United Nations MDGs are silent on the issue of quality, focussing on achieving 'universal primary education' (United Nations, 2000, Goal 2), we see evidence - for example, the publication of the 2005 EFA Global Monitoring Report, entitled Education for All: The Quality Imperative (UNESCO, 2004) - that quality had at least moved closer to center stage.

Educational quality has increasingly been defined less in terms of inputs and processes and more often in relation to student learning outcomes. However, the focus on learning outcomes 454 has tended to focus narrowly on academic knowledge and skills (particularly literacy and numeracy), and not included explicit attention to developing awareness, commitments, and capacities related to transforming national and global society in order to achieve human rights for all.

There is a counter movement. Of particular note is the emphasis on twenty-first century skills as key to preparing learners, regardless of age or stage in the education system, to be able to function successfully in a fast-changing world. For instance, Trilling and Fadel (2009) argue that the full range of skills such as critical thinking, problem solving, communication, team work, and digital literacy are even more important today than ever before. They are skills that must be mastered as they are the ones that enable learners to adapt to and engage with their environments over their lifetimes.

\section{Opportunities and challenges for improving educational quality}

Given the desire to improve education systems, what do we know about the process? Assuming sufficient commitment to educational reform (or what is sometimes called educational development) focussed on achieving human rights for all, the question remains whether, under what conditions, over what time period, and how education systems can be changed. Here we will focus on answering these questions in relation to 'developing' countries, drawing on a recently completed, comparative study of long-term (1990-2009) education system reform in Egypt, El Salvador, Namibia, Nicaragua, and Zambia. Education System Reform and Aid Effectiveness: The Power of Persistence (Gillies, 2010: 96-101), ${ }^{2}$ the monograph summarizing this research, draws conclusions such as the following:

- Changes in governance and management structures, teaching and learning processes, standards and assessment systems, and levels/ forms of civil society involvement in education take place, though often only in localized contexts supported for a relatively short period of time. 


\section{Ginsburg et al: Introduction}

- Broader and deeper changes in these aspects of education also occur, but are achieved over a considerable period of time, with the movement by no means being constant or linear.

- Some of the educational changes that occur are sustained, though others either wither away or are discarded as new reform initiatives are undertaken, depending not only on the commitments and actions of key stakeholders but also on developments within the national and international context.

- Educational change, thus, requires engaging over time in concerted actions (policy reform, capacity building, mobilizing resources, and attracting political support) as well as monitoring change efforts with consistent attention to political, economic, and cultural dynamics at institutional, national, and international level.

- International education development projects, funded and organized through different modalities, can foster conditions for reform, create a stimulus for reform, and enable processes that create mutually reinforcing incentives for reform.

- Sustainability is more complex than simply continuing project activities or initiatives; sustaining efforts to improve educational quality requires ownership by a broad base of political leaders, system managers, professional staff, parents, and civil society, supported by policies and procedures that reinforce behaviour and provide incentives.

- Finally, the availability of adequate financial resources is a necessary, but not sufficient condition; thus attention must be given to securing funds from various sources and deploying them efficiently.

\section{Conclusion}

Access to education - and, particularly, high-quality education - is a human right, and thus should be guaranteed for all people in the world. In addition, education is also an important, but obviously not the only, institution that can contribute to creating the conditions (commitments, capacities, and structures) for realizing other (economic, political, and social) human rights. Nevertheless, while education can (and should) be organized so that it promotes human rights, we need to be mindful that, at various times and places, education has served to reproduce societal arrangements that deny certain groups and individuals their human rights. Thus, our efforts must be focussed on reforming education in ways that enable the system, the people that work in it, and the direct and indirect clients whom it serves to transform national and global societies so that all people recognize and experience human rights. This necessitates placing human rights at the center of efforts to reform education and engaging in concerted actions over the long term. This is not to suggest that the goal of reforming education, let alone transforming society, is easy, but rather to acknowledge that the alternative is untenable.

EFA and the specific MDG commitments have provided an extraordinary opportunity for the world to focus on education and, increasingly, on its purposes. There are signs of progress towards creating more inclusive education systems, which focus on the needs, values, concerns, and aspirations of diverse populations as well as contribute in a potentially transformative way to promote commitments to and realization of human rights for all.

\section{Notes}

1 A somewhat similar categorization is proffered by Marshall (1964: 72), who distinguishes among political, civil, and social entitlements of citizenship, with the latter entitlement pertaining to the rights to have a modicum of economic welfare and security, to share in the full social heritage, and to live the life of a civilized being according to the standards prevailing in the society'.

2 The following individuals collaborated in undertaking the specified case studies: Egypt (Mark Ginsburg, Nagwa Megahed, Mohammed Elmeski, and Nobuyuki Tanaka); El Salvador (Jessica Jester Quijada, John Gillies, and Antonieta Harwood); Namibia (Donna Kay LeCzel, Muhamed Liman, Sifiso Nyathi, Michael Tjivikua, and Godfrey Tubaundule); Nicaragua (John Gillies, Kirsten Galisson, Anita Sanyal, and Bridget Drury); and Zambia (David Balwanz and Arnold Chengo). 


\section{Development 53(4): Upfront}

\section{References}

Altbach, Philip G. and Gail P. Kelly (1978) Education and Colonialism, New York, NY: Longman.

Beeby, Clarence Edward (1966) The Quality of Education in Developing Countries, Cambridge, MA: Harvard University Press.

Bernstein Tarrow, Norma (ed.) (1987) Human Rights and Education, New York, NY: Pergamon Press.

Bourdieu, Pierre and Jean Claude Passeron (1977) Reproduction in Education, Society, and Culture, Beverly Hills, CA: Sage Publications.

Brown, Phillip and Hugh Lauder (1997) 'Education, Globalization, and Economic Development', in Albert H. Halsey, Hugh Lauder, Phillip Brown and Amy Stuart Wells (eds.) Education, Culture, Economy, and Society, pp 172-92, New York, NY: Oxford University Press.

Counts, George S. (1932) Dare the School Build a New Social Order?, New York, NY: John Day Company.

Daun, Holger (ed.) (2002) Educational Restructuring in the Context of Globalization and National Policy, New York, NY: RoutledgeFalmer.

Gillies, J. (2010) Education System Reform and Aid Effectiveness: The power of persistence, Washington, DC: AED and USAID/EQUIP 2.

Ginsburg, Mark B. (ed.) (1991) Understanding Educational Reform in Global Context: Economy, ideology and the state, New York, NY: Garland Publishing.

Ginsburg, Mark B. (ed.) (1995) The Politics of Educators' Work and Lives, New York, NY: Garland.

Ginsburg, Mark B. and Susan F. Cooper (1994) 'Conceptual Issues in Educational Reform', in Abraham Yogev and Val D. Rust (eds.) International Reform in International Perspective, pp 55-80, Greenwich, CN: JAI Press.

Giroux, Henry A. (1983) Theory and Resistance in Education: A pedagogy for the opposition, South Hadley, MA: Bergin and Garvey Publishers.

Inter-Agency Commission (1990) World Declaration on Education for All Document adopted by the World Conference on Education for All: Meeting Basic Learning Needs, Jomtien, Thailand, 5-9 March, 1990. New York, NY: InterAgency Commission.

Kreisberg, Seth (1992) Transforming Power: Domination, empowerment, and education, Albany, NY: State University of New York Press.

Marshall,Thomas H. (1964) Class, Citizenship, and Social Development, New York, NY: Doubleday.

Morrow, Raymond Allen and Carlos Alberto Torres (1995) SocialTheory and Education: Critique of theories of social and cultural reproduction, Albany, NY: State University of New York Press.

Paulston, Rolland G. (ed.) (1996) Social Cartography: Mapping ways of seeing social and educational change, New York, NY: Garland.

Pigozzi, Mary Joy (2010) 'Quality Education - A UNESCO Perspective’, in Joel Cohen and Martin Matlin (eds.) International Perspectives on the Goals of Universal Basic and Secondary Education, pp 235-45, New York, NY: Routledge.

Quick, Robert Herbert (1868) Educational Reformers, London: Longmans Green.

Simmons, John (1983) 'Reforming Education and Society: The enduring quest', in John Simmons (ed.) Better Schools: International lessons for reform, pp 3-19, New York: Praeger.

Spring, Joel (2000) The Universal Right to Education: Justification, definition, and guidelines, pp 157-63, Mahwah, NJ: Lawrence Erlbaum Associates, Publisher.

Tomasevski, Katarina (2006) Human Rights Obligations in Education:The 4-A scheme, Nijmegen,The Netherlands: Wolf Legal Publishers.

Trilling, Bernie and Charles Fadel (2009) 21st Century Skills: Learning for life in our times, San Francisco, CA: JosseyBass.

United Nations (1948) UN Declaration of Human Rights, New York, NY: United Nations.

United Nations (2000) Millennium Development Goals, New York, NY: United Nations.

UNESCO (2000) 'The Dakar Framework for Action: Education for all: Meeting our collective commitments', Text adopted by the World Education Forum, Dakar, Senegal, 26-28 April, Geneva: UNESCO.

UNESCO (2004) Education for All: The quality imperative, EFA Global Monitoring Report 2005, Geneva: UNESCO. 